\title{
Infiltration Rate of Pervious Concrete on Street Curb Application
}

\author{
Aifaa Balqis Kamarul Zaman,Zahiraniza Mustaffa, Lea Doleeda Luncha Anak Giri
}

\begin{abstract}
The street curb and stormwater inlets are among the component often found on the road which serve as part of the urban stormwater drainage system. They act as a stormwater removal and discharge it into the underground drainage system. However, the current stormwater inlet practiced in Malaysia has limitations which often cause water ponding and consequently lead to road flooding. Rather than improving the performance of stormwater inlet, the flow interception and rate of stormwater removal may be enhanced by introducing a new technology called the pervious curb. It isto be made of pervious concrete which provide an ability to allow water to pass through it.This paper attempts to adapt the existingtwo pervious concrete mix design and applied it into the so-called pervious curb. Herein, a newly designed infiltration rate test was used to test the pervious concrete performance under the effect of infiltration through side surface of the concrete curb. While doing so, the infiltration rate of the pervious concrete will be investigated under varying slopes. Results showed that the infiltration rate is quite high and the rate of infiltration increases as the inclination gutter increases. Thus, it is proven that the new infiltration rate test is applicable and can be used for other similar applications. Furthermore, the test has significantly revealed that the pervious concrete has high potential in enhancing flow interception and able to reduce water ponding as a street curb.
\end{abstract}

Index Terms: infiltration rate, pervious concrete, street curb, stormwater inlet

\section{INTRODUCTION}

Every street pavement is made to serve traffic movement and it would always serve with drainage function. The purpose of having the street with drainage system is to ensure that water flows on the street surface will be able to be removed and conveyed into another stormwater drainage system underground. Generally, a street pavement is not flat. It is made with slopes component to enable a good drainage system to take place. The slopes mentioned are the longitudinal, transversal and gutter slopes. Meanwhile, stormwater inlet is the other important part of the street component that collects and removes stormwater from the street into underground drainage system.

Revised Manuscript Received on June 22, 2019.

Aifaa Balqis Kamarul Zaman, Department of Civil and Environmental Engineering, Universiti Teknologi PETRONAS, 32160 Bandar Seri Iskandar, Perak, Malaysia

Zahiraniza Mustaffa, Department of Civil and Environmental Engineering, Universiti Teknologi PETRONAS, 32160 Bandar Seri Iskandar, Perak, Malaysia

Lea Doleeda Luncha Anak Giri, Department of Civil and Environmental Engineering, Universiti Teknologi PETRONAS, 32160 Bandar Seri Iskandar, Perak, Malaysia

Basically, there are four types of stormwater inlet practiced in Malaysia, namely grate inlet, curb-opening inlet, combination inlet and slotted drain inlet [1]. Unfortunately, although the street has been installed with those inlets, it is often found inefficient in removing stormwater. The design of stormwater inlet in Malaysia is too simple that the stormwater will always end up being accumulated and widely spread on the street (Fig. 1). This is a concerned and will bring traffic hazards for Malaysian traffic users. In addition, Malaysia has a tropical climate thus the amount of stormwater received are high throughout the year. Besides, urbanization has led Malaysia to replace most of the vegetative lands with impervious surface such as street pavement. The replacement has become a major problem because these impervious surfaces of street pavement has reduced the natural infiltration area and thus increase the amount of stormwater to flow on the street [13]. Eventually, the problem has contributed to water ponding or flooding whereby it gives unpleasant impacts to the traffic user as it disturbs their routine and possibly lasts for quite some time [23].

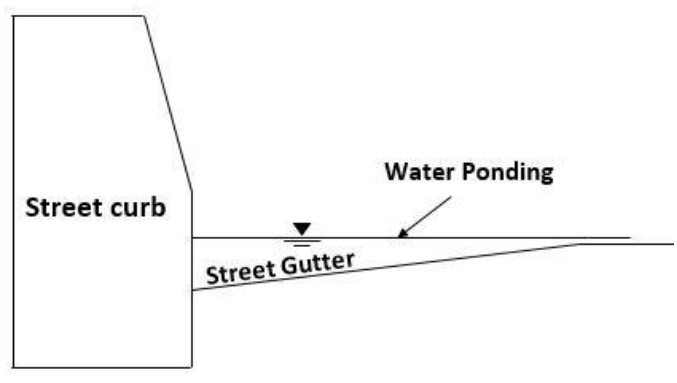

Fig. 1 Water ponding

Therefore, it should be highlighted here, on the importance to ensure the drainage system especially stormwater inlet to be well designed and performed efficiently to cater huge amount of the stormwater Basically, a lot of studies related to stormwater inlet have been carried out by researchers. It has been found that the hydraulic behaviour of stormwater inlet is complex to be understood[12,21]. Due to this, experimental and numerical research work on stormwater inlet mainly investigating on inlet performance and efficiency have been conducted [3, $11,12,19,20,26,28,29]$. Based on previous research, it can be concluded that the hydraulic performance of stormwater inlet could be improved by either increasing the inlet spacing or number of inlets. Modifications could also be made on the stormwater inlet design through dimension, the grate geometry or both [29]. 
However, improving the performance of stormwater inlet does not seem to be enough to overcome water ponding and to enhance management of the urban stormwater drainage system.

As an alternative solution, pervious road pavement technology has been widely introduced. It has been well recognized by Environmental Protection Agency (EPA) as one of the Best Management Practice (BMP) for sustainable stormwater management to prevent road flooding. This technology has the ability to allow stormwater to infiltrate directly through the surface of the pavement into sub drainage and thus give a tremendous benefit to improve stormwater management and environment [2, 27]. A lot of research has been conducted on the pervious street pavement that investigate the behaviour, strength and improvement on the applications $[17,18]$. However, to fully implementing pervious street pavement is not easy since the construction of the pavement face more challenge as compared to the conventional pavement because it has more requirement to be fulfilled.

There are a lot of barrier to overcome and factor to be considered as recently reported by [25] where there is still lack of expertise, insufficient information related to pervious pavement and others. Therefore, instead of having pervious street pavement which is more challenging, costly and large scale, a new sustainable technology known as pervious curb is to be introduced in this research as another alternative solution. Basically, pervious curb is mainly to be made of pervious concrete or also well-known as high permeable concrete or porous concrete $[16,27]$. The materials used in this concrete are similar to those in the impervious concrete, except it contains little or no fine aggregates which creates high voids and hence enabling water to infiltrate through it [10, 31].

The main reason of bringing the pervious road curb idea is that during the stormwater event, it is quite common to observe the excess stormwater runoff accumulated and concentrated between the street curb and gutter. Even though the street curb is equipped with stormwater inlet, it still has certain limitations and insufficient to completely get rid of the water ponding.Therefore, by applying pervious concrete onto the street curb, the stormwater was expected will be able to directly infiltrate into side surface of the pervious curb. Rather than letting the impervious street curb to act as a barrier only, this new technology can be highly utilized as part of the stormwater drainage system. It has high potential to enhance the rate of stormwater removal thus reduce water ponding on the road. Therefore, this research aims to design a new infiltration rate test set up specifically for pervious concrete application on the road curb. While doing so, the infiltration rate and flow net of the concrete will also be investigated.

\section{LITERATURE REVIEW}

\section{Pervious Concrete}

Through definitions, pervious concrete is a type of concrete that has high porosity, allowing the infiltration of water through it [32] as shown in Fig. 2. Its high porosity is achieved through the main ingredients used in the mixture which consists of cementing materials, coarse aggregate, water and admixtures [16]. The materials is the same as used the impermeable concrete but without fine aggregate [5]. Due to the non-existence of fine aggregate in it, it is sometimes known as "no-fines" concrete [7]. This creates voids and hence, enabling water to infiltrate through it. Moreover, [14] defined pervious concrete as a technology that produces an ecological and sustainable alternative.

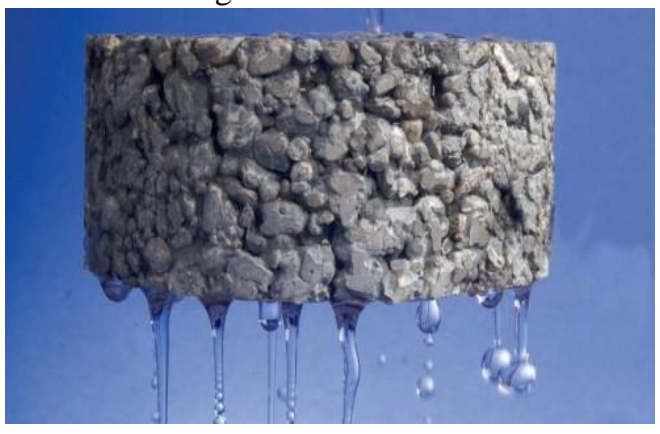

Fig. 2 Pervious concrete water infiltration

Hu et al. (2018) [24] pointed out that there are three types of pervious concrete, namely pervious asphalts (PA), pervious concretes (PC) and pervious interlocking concrete pavers (PICP). Based on the study that has been carried out by [24], PC performs the best among the three types of pervious concretes in terms of its hydrological performance (without clogging), followed by PA and PICP. In getting the right mixture for pervious concrete, there are several requirements to be considered which need to compromise the optimum environmental and strength properties of the concrete [9] once it overlaying as the surface course. The paste of the pervious concrete should be made of an adequate amount of water and cementitious material in order to get the optimum thickness of the coating to bind the aggregate particles together [5].

On the other hand, chemical admixtures are not necessary used for the mixture of the concrete. In order to improve the quality of the pervious concrete, other ingredients that can be added in the mixture such as recycled concrete and waste of the industry [32]. Typically, a pervious concrete should content a compressive strength approximately 28 to 281 $\mathrm{kg} / \mathrm{cm} 2$ while void ranges from $18 \%$ to $35 \%$ [15]. Since pervious concrete is a product that specially made to allow water to pass through, infiltration rate must be higher than conventional impervious concrete. As reported by [15], the infiltration rate of pervious concrete should be in the range of 80 to 720 litre $/ \mathrm{m}^{2} / \mathrm{min}$.It should be noted that, as pervious concrete contains high voids, it becomes more porous.

\section{Advantages of Pervious Concrete}

The application of pervious concrete does give a lot of benefits especially to the environment and stormwater management. Stormwater management using pervious concrete are commonly being applied in the urban areas compared to rural areas. It is understandable why the urban areas need this technology more than the rural areas. Iya et al. (2014) [23] pointed out a that flash floods occur in the urban areas more often as it is prone to having an increasing number of buildings and inefficient drainage system. 
Apart from managing stormwater for the drainage system, these concrete carries more environmental benefits. As it is known, pervious concrete allows water infiltration. This automatically will reduce the surface runoff and peak flows [6] and eventually improves water quality by reducing the number of pollutants and microbial degradation before the infiltrated water reaches the sub-surface layers [22]. Not to mention, groundwater would be able to be recharged and replenished as well [32].

In terms of safety, pervious concrete has better skid resistance. This is because it can absorb the surface runoff better than the impervious concrete pavement [8]. It improves the safety of the road users during rainy days by reducing water ponding and glare at night $[5,30]$. James and Langsdorff (2003) [22] said that the natural vegetation helps to improve water quality too by allowing the water to be filtrated, deposited, infiltrated, absorbed, adsorbed, decomposed and volatilized. In Europe and Japan, the high permeable concrete is applied in highway pavements for two factors, its ability to be skid resistant and quiet [9].

A positive impact that the pervious concrete can give is by benefiting the growth of the plant. This happens during the high infiltration rate through the concrete. Due to easier infiltration through the pervious concrete, the root of plants gets both water and oxygen [4]. The high cost of underground piping systems can be eliminated [32]. When high permeable concrete is applied as the pavement, there is no longer need of having the regular drainage system which consists of storm drains, gutters and curbs [32].

\section{RESEARCH METHODOLOGY}

This section describes the methodology of the research. Explanation will first be given on the mix design proportions selected followed by the preparation procedures of the pervious concrete cube. Note that, the application of the pervious concrete is for the street curb, the infiltration rate test on the pervious concrete cube sample needs to be modified in order to fit the purpose. Therefore, the newly designed infiltration rate test is designed for the pervious concrete cube sample is introduced.

\section{A. Pervious Concrete Mix Design Proportions}

The mix design of the nano-silica modified pervious concrete was adapted from an existing mix design established by Mohammed et al. (2018) [16]. The mix design consisted of Ordinary Portland Cement (OPC), fly ash (FA), nano-silica (NS), water, coarse aggregate and superplasticizer (SP). It should be noted that FA class F was used as cement replacement while SP Sika ViscoCrete-4100 addition as water reducing admixture. For the coarse aggregate, nominal size of $10 \mathrm{~mm}$ was used. Basically, this concrete has the same properties as the regular pervious concrete, except it was modified with an additive NS to strengthen the concrete. There are nine mixtures proportions reported in Mohamed et al. (2018)but only two were selected in the present work. The two chosen mix designsproportions, namely Mix A and Mix B are as shown in Table 1.

\section{B. Pervious Concrete Preparations}

Three concrete cube samples size of $100 \times 100 \times 100 \mathrm{~mm}$ was prepared for each mix. All samples were left hardened

for 24 hours. Since this research was not concerned on the strength parameters, no curing was required. With these steps, the final outcomes of the mixes are as shown in Fig. 3.

Table. 1 Mixture proportions of pervious concrete by Mohammed et al. (2018)

\begin{tabular}{|c|c|c|c|c|c|c|c|}
\hline Mix & $\begin{array}{c}\text { Paste/Agg. } \\
\text { Ratio }\end{array}$ & $\begin{array}{l}\text { FA } \\
(k g \\
\left./ m^{3}\right)\end{array}$ & $\begin{array}{c}\text { Cemen } \\
\mathrm{t} \\
(\mathrm{kg} \\
\left./ \mathrm{m}^{3}\right)\end{array}$ & $\begin{array}{c}\text { Water } \\
\left(\mathrm{kg} / \mathrm{m}^{3}\right)\end{array}$ & $\begin{array}{l}\text { Coarse } \\
\text { Agg. } \\
(\mathrm{kg} \\
\left./ \mathrm{m}^{3}\right)\end{array}$ & $\begin{array}{l}\mathrm{NS} \\
(\mathrm{kg} \\
\left./ \mathrm{m}^{3}\right)\end{array}$ & $\begin{array}{l}\mathrm{SP} \\
(\mathrm{kg} \\
\left./ \mathrm{m}^{3}\right)\end{array}$ \\
\hline A & 0.297 & 134.87 & 350 & 145.46 & 2649 & 11.416 & 6.25 \\
\hline B & 0.382 & 224.78 & 250 & 142.43 & 2040 & 11.416 & 6 \\
\hline
\end{tabular}

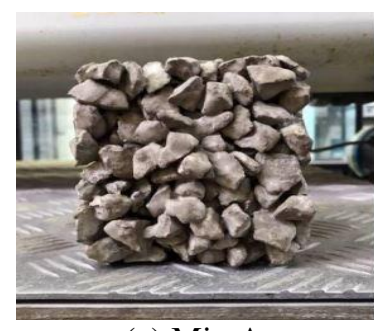

(a) Mix A

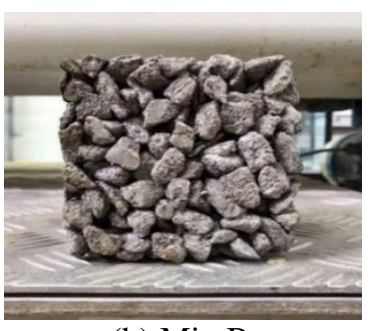

(b) Mix B

Fig. 3 Concrete cube samples

\section{Newly Designed Infiltration Rate Test}

The typical infiltration rate test was normally carried out using a cylindrical ring. The ring is opened at both ends and water will be poured directly into the ring. Note that this pervious concrete will be applied for the street curb thus the water infiltration will take place mainly on the side surface of the curb. Therefore, the test was redesigned to replicate and simulate the actual condition of water infiltration into the pervious concrete street curb.

Basically, a new infiltration rate device was designed specifically to perform side surface infiltration. The device was fabricated using perspex material and divided into two parts, namely gutter part and curb part, as shown in Fig. 4. The gutter part was equipped with a hole to allow water to be filled up. It was made to be horizontally inclined to replicate the actual street gutter slope. It should be highlighted that the device was designed at varying slope ranging from $1^{\circ}$ to $4^{\circ}$, to suit the gutter slope of the street. The purposes of varying the slope is to analyse the relationship between the degree of slope with the infiltration rate and flow patterns of the pervious concrete.

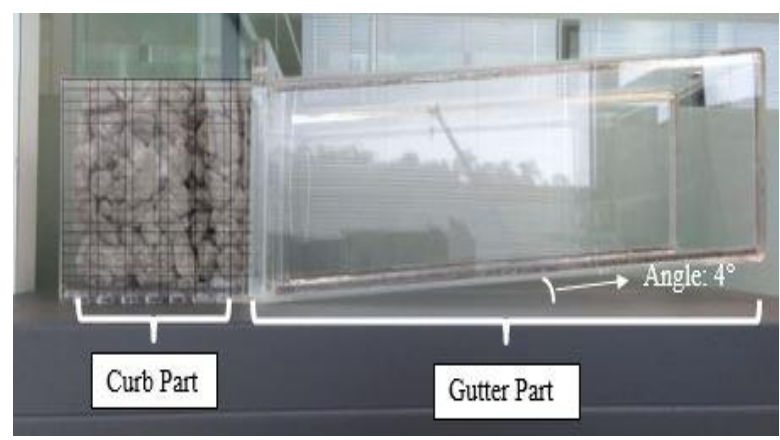

Fig. 4 Side view of infiltration rate device 
On the other hand, the curb part was designed in a cube shape that was purposely made for concrete cube sample to fit in. Besides, it can be seen that the bottom surface of the curb part was designed to be having many holes, to drain out excess water from the concrete. Note that, the newly designed infiltration rate device has been patented.

\section{Infiltration Rate Test Procedure}

Basically, the infiltration rate test was carried out horizontally inclined, to allow water to infiltrate directly from the side surface pervious concrete. Firstly, the concrete cube sample is to be placed at the curb part of the device. Then, the removable perspexis slide in so that water can flow in and fully fill up the gutter part of the device. Once it is full, the removable perspex is slide out. At the same time, start the timer and stop when there is no more water to be infiltrated into the pervious concrete. Record the time taken for water to fully infiltrate into the pervious concrete. Repeat the procedure but with different slope of $2^{\circ}$ and $4^{\circ}$. The infiltration rate can be computed using formula created by Shinde \& Valunjkar (2015) which is expressed as,

$$
\text { Infiltrationrate }=V / A / t
$$

Where $V$ is the measured volume of water (litre), $A$ is the cross-section area of concrete cube in $\left(\mathrm{m}^{2}\right)$ and $t$ is the time required for entire volume of water to fully infiltrated $(\mathrm{min})$.

\section{RESULTS \& DISCUSSION}

The infiltration rate test involved investigating the velocity or speed of the water seeping into the pervious concrete under varying slopes. The infiltration rate was computed using Eq. 1 and the results for the two concrete cube sample are shown in Table 2. It should be noted that the volume of water and area of the concrete cube are 3 litres and $0.01 \mathrm{~m}^{2}$ respectively and the value was the same throughout the test.

Table. 2 Results of infiltration rate

\begin{tabular}{|c|c|c|c|c|c|c|}
\hline \multirow[t]{2}{*}{$\begin{array}{l}\text { Slope } \\
\text { Degre } \\
\quad \text { e }\end{array}$} & \multicolumn{2}{|c|}{ Time (min) } & \multicolumn{2}{|c|}{$\begin{array}{c}\text { Infiltrationrat } \\
\text { e (litre } / m^{2} / \\
\text { min })\end{array}$} & \multicolumn{2}{|c|}{$\begin{array}{l}\text { Avg.Infiltratio } \\
\text { n Rate } \\
\left(\text { litre } / \mathbf{m}^{2} /\right. \\
\text { min })\end{array}$} \\
\hline & Mix A & $\begin{array}{c}\text { Mix } \\
\text { B }\end{array}$ & $\begin{array}{c}\text { Mix } \\
\text { A }\end{array}$ & Mix B & $\begin{array}{c}\text { Mix } \\
\text { A }\end{array}$ & Mix B \\
\hline \multirow{3}{*}{$1^{\circ}$} & 0.146 & 0.144 & 2058 & 2077 & \multirow{3}{*}{2135} & \multirow{3}{*}{2241} \\
\hline & 0.135 & 0.132 & 2221 & 2274 & & \\
\hline & 0.141 & 0.126 & 2126 & 2373 & & \\
\hline \multirow{3}{*}{$2^{\circ}$} & 0.129 & 0.100 & 2318 & 2921 & \multirow{3}{*}{2348} & \multirow{3}{*}{2602} \\
\hline & 0.127 & 0.121 & 2364 & 2474 & & \\
\hline & 0.127 & 0.124 & 2364 & 2411 & & \\
\hline \multirow{3}{*}{$4^{\circ}$} & 0.079 & 0.117 & 3798 & 2559 & \multirow{3}{*}{3254} & \multirow{3}{*}{2629} \\
\hline & 0.084 & 0.110 & 3579 & 2726 & & \\
\hline & 0.126 & 0.115 & 2386 & 2603 & & \\
\hline
\end{tabular}

By average, it is revealed that the infiltration rate increases as the slope degree increases. This is true because as higher slope degree prone to exert higher velocity, thus more water would easily flow and infiltrate through the concrete at higher rate. For instance, water infiltration rate would be lower for lower slope of $1^{\circ}$.

Overall, the result obtained has clearly revealed that the average infiltration rate for pervious concrete mixA and mix $\mathrm{B}$ under varying slopes are in the range between 1298to 3254 litre $/ \mathrm{m}^{2} / \mathrm{min}$ and 2277to 2629 litre $/ \mathrm{m}^{2} / \mathrm{min}$, respectively.

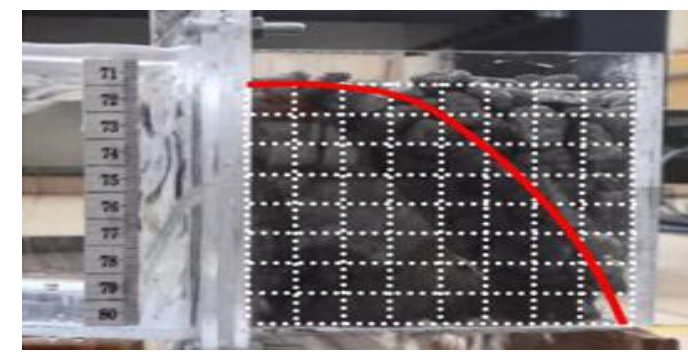

Fig. 5 Superimposed maximum infiltration flow net area

The coverage of water interception was visually recorded and later mapped with scales, as shown in Fig.5. This was illustrated as the flow net from the side view, through which the water seeps into.The equation for the computation of maximum infiltration flow net area is given by,

Max. infiltration $=$ No. of squares $\times$ Area of square flow net area

Taking mix design B; for instance, the superimposed flow net has brought to the calculations of the maximum infiltration flow net area and total percentage of maximum infiltration flow net area as below. As shown in the calculations, the value of 47.75 represents the total of squares infiltrated by the water as per the scaled grids drawn on the side wall of the curb part. The grid was drawn at $0.0125 \times 0.0125 \mathrm{~m}$ scale.

Max. infiltration flow net area for mix B

$=47.75(0.0125 \times 0.0125) \mathrm{m}$

$=0.00746 \mathrm{~m}^{2}$

Total \% of max. infiltration flow net area mix B

$==(0.00746 / 0.01000) m^{2} \times 100 \%$

$=74.6 \%$

\section{CONCLUSION}

A newly designed infiltration rate test was used to obtain the infiltration rate. Under varying slopes, the result of infiltration rate revealed that for pervious concrete sample $\mathrm{A}$, it is fall in the range of 1298 to 3254 litre $/ \mathrm{m}^{2} /$ minmeanwhile concrete sample $\mathrm{B}$, it was in the range between 2277 to 2629 litre $/ \mathrm{m}^{2} / \mathrm{min}$. On the other hand, the percent of maximum infiltration flow net area obtained was $74.6 \%$ for sample concrete B.In conclusion, the objectives of this research have been achieved. The results obtained are more than satisfying. Since the expected results are obtained, it can be said that the pervious concrete is proven to be able used on pervious curb application. It has advantages to intercept and remove stormwater on the road efficiently. With this new technology, water ponding can be minimised and thus improve the management of urban stormwater drainage system in Malaysia. 


\section{REFERENCES}

1. Department of Irrigation and Drainage, "Urban Stormwater Management Manual Malaysia," DID Malaysia, Kuala Lumpur, 2012

2. N. Xie, M. Akin and X. Shi, "Permeable concrete pavements: A review of environmental benefits," Journal of Cleaner Production, vol. 210, pp. 1605-1621, 2019.

3. C. P. Wu, T. S. Yu, A. S. T. Wong and C. W. Li, "Hydraulic interception efficiency of gully gratings on steep roads," HKIE Transactions, vol. 22, no. 3, pp. 192-198, 2015.

4. A. Volder, T. Watson and B. Viswanathan, "Potential Use of Pervious Concrete for Maintaining Existing Mature Trees During and After Urban Development," Urban Forestry and Urban Greening, vol. 8, no. 4, pp. 249-256, 2009.

5. P. D. Tennis, M. L. Leming and D. J. Akers, "Pervious Concrete Pavements," Portland Cement Association, Skokie, Illinois, and National Ready Mixed Concrete Association, Silver Spring, Maryland, 2004.

6. M. Sonebi, M. Bassuoni and A. Yahia, "Pervious Concrete: Mix Design, Properties and Applications," RILEM Technical Letters, vol. 1, p. 109, 2016.

7. D. S. Shah, J. Pitroda and J. J. Bhavsar, "Pervious Concrete: New Era for Rural Road Pavement," International Journal of Engineering Trends and Technology (UETT, vol. 4, no. 8, pp. 3495-3499, 2013.

8. D. S. Shah, J. Pitroda and J. J. Bhavsar, "Pervious Concrete: New Era for Rural Road Pavement," International Journal of Engineering Trends and Technology (UETT, vol. 4, no. 8, pp. 3495-3499, 2013.

9. V. R. Schaefer, M. T. Suleiman, K. Wang, J. Y. Kevern and P. Wiegand, "An Overview of Pervious Concrete Application in Stormwater Management and Pavement System," Civil, Construction and Environmental Engineering, Iowa State University, Ames, LA, 2006.

10. S. A. Salih, I. N. Gorgis and W. F. Abd, "Some Properties of No-Fines Concrete Produced by Using Demolished Concrete as Recycled Coarse Aggregate," Engineering and Technology Journal, vol. 35, no. 7, pp. 741-748, 2017.

11. B. Russo, M. Gomez and J. Tellez, "Methodology to Estimate the Hydraulic Efficiency of Nontested Continuous Transverse Grates," Journal of Irrigation \& Drainage Engineering, vol. 139, no. 10, pp. 864$571,2013$.

12. M. Rubinato, S. Lee, R. Martins and J. Shucksmith, "Surface to sewer flow exchange through circular inlets during urban flood conditions," Journal of Hydroinformatics, pp. 1-13, 2018.

13. A. Rose, J. E. Wilson and L. M. Lavkulich, "Analysis of Impervious Surface Area, and the Impacts on Soil-Based Agriculture and the Hydrologic Cycle: A Case Study in the Agricultural Land Reserve in Metro Vancouver, British Columbia, Canada.," Agricultural Sciences, vol. 8, pp. 837-856, 2017.

14. S. Rahman, A. B. Northmore, V. Henderson and S. L. Tighe, "Developing A Framework for Low-Volume Road Implementation of Pervious Concrete Pavements," International Journal of Transportation Science and Technology, vol. 4, no. 1, pp. 77-92, 2016.

15. K. H. Obla, "Pervious concrete - an overview," Indian Concrete Journal, vol. 84, no. 8, pp. 9-18, 2010.

16. B. S. Mohammed, M. S. Liew, W. S. Alaloul, V. C. Khed, C. Y. Hoong and M. Adamu, "Properties of nano-silica modified pervious concrete," Case Studies in Construction Materials, pp. 409-422, 2018.

17. A. Mohammadinia, M. M. Disfani, G. A. Narsilio and L. Aye, "Mechanical behaviour and load bearing mechanism of high porosity," Construction and Building Materials, vol. 168, pp. 794-804, 2018.

18. G. Lu, L. Renken, T. Li, D. Wang, H. Li and M. Oeser, "Experimental study on the polyurethane-bound pervious mixtures in the," Construction and Building Materials, pp. 838-850, 2019.

19. P. Lopes, J. Leandro, R. F. Carvalho, B. Russo and M. Gomez, "Assessment of the Ability of a Volume of Fluid Model to Reproduce the Efficiency of a Continuous Transverse Gully with Grate," Journal of Irrigation and Drainage Engineering, vol. 142, no. 10, pp. 1-9, 2016.

20. P. Lopes, J. Leandro, R. F. Carvalho, P. Pascoa and R. Martins, "Numerical and experimental investigation of a gully under surcharge conditions," Urban Water Journal, pp. 1-9, 2013.

21. S. Kemper and A. Schlenkhoff, "Capacity of street inlets with partially severed grate openings," International Junior Researcher and Engineer Workshop on Hydraulic Structures, 2016

22. W. James and H. Langsdorff, "The Use of Permeable Concrete Block Pavement in Controlling Environmental Stressors in Urban Areas," 7th International Conference on Concrete Block Paving, pp. 1-8, 2003.
23. S. G. D. Iya, M. B. Gasim, M. E. Toriman and M. G. Abdullahi, "Floods in Malaysia: Historical Reviews, Causes, Effects and Mitigations Approach," International Journal of Interdisciplinary Research and Innovations, vol. 2, no. 4, pp. 59-65, 2004.

24. M. Z. Hu, Y. L. Siu, L. Yu, K. Tanaka, Y. Hong and Y. Xu, "Flood Mitigation by Permeable Pavements in Chinses Sponge City Construction," Water, vol. 10, no. 2, pp. 1-12, 2018.

25. J. Harvey and D. R. Smith, "Final Report: Permeable Pavement Road Mao Workshop and Proposed Road Map for Permeable Pavement," 2018.

26. J. C. Y. Guo, K. A. MacKenzie and A. Mommandi, "Flow Interception Capacity of Inclined Grate," Journal of Irrigation \& Drainage Engineering, vol. 142, no. 4, pp. 1-5, 2016.

27. I. N. Grubesa, I. Barisic, V. Ducman and L. Korat, "Draining capability of single-sized pervious concrete," Construction and Building Materials, pp. 252-260, 2018.

28. M. Gomez and R. Beniamino, "Hydraulic Efficiency of Continuous Transverse Grates for Paved Areas," Journal of Irrigation \& Drainage Engineering, vol. 135, no. 2, pp. 225-230, 2009.

29. M. Gomez, J. Recasens, B. Russo and M. E. Gomariz, "Assessment of inlet efficiency through a 3D simulation: numerical and experimental comparison," Water Sciences \& Technology, vol. 74, no. 8, pp. 1926 $1935,2016$.

30. W. Goede, "Investigation into the Structural Performance of Pervious Concrete", Journal of Transportation Engineering, vol. 138, no. 1, pp. 98-104, 2012.

31. S. Eathakoti, N. Gundu and M. R. Ponnada, "An Innovative No-Fines Concrete Pavement Model," Journal of Mechanical and Civil Engineering, vol. 12, no. 5, pp. 34-44, 2015.

32. D. M. Abdel Aziz, D. O. Al-Maani and W. Al-Azhari, "Using Pervious Concrete for Managing Storm Water Run-off in Urban Neighbourhoods: Case of Amman," American International Journal of Contemporart Research, vol. 5, no. 2, pp. 76-78, 2015. 